\title{
New records of Burgess Shale-type taxa from the middle Cambrian of Utah
}

\author{
Simon Conway Morris, ${ }^{1}$ Paul A. Selden, ${ }^{2,3}$ Glade Gunther, ${ }^{4}$ Paul G. Jamison, ${ }^{5}$ and Richard A. Robison ${ }^{2}$ \\ ${ }^{1}$ Department of Earth Sciences, University of Cambridge, Cambridge, CB2 3EQ, UK <sc113@cam.ac.uk> \\ ${ }^{2}$ Department of Geology, University of Kansas, Lawrence, Kansas 66045-7594, USA < selden@ku.edu>; <rrobisn@ku.edu> \\ ${ }^{3}$ Natural History Museum, London, SW7 5BD, UK \\ ${ }^{4}$ Brigham City, Utah 84302, USA < glade@geo-tool.com> \\ ${ }^{5}$ JPS Inc., Logan, Utah 84321, USA <info@SpenceShaleFossils.com>
}

\begin{abstract}
Cambrian strata of the Laurentian craton contain numerous examples of Burgess Shale-type faunas. Although displaying a more or less concentric distribution around the cratonal margin, most faunal occurrences are in present-day western North America, extending from the Northwest Territories to California. Nevertheless, the soft-bodied and lightly skeletalized fossils in most of these Lagerstätten are highly sporadic. Here, we extend knowledge of such Middle Cambrian occurrences in Utah with reports of four taxa. An arthropod from the Marjum Formation, Dytikosicula desmatae gen. et sp. nov., is a putative megacheiran. It is most similar to Dicranocaris guntherorum, best known from the younger Wheeler Formation, but differs primarily in the arrangement of pleurae and overall size. Along with a specimen of ?Yohoia sp, a new species of Yohoia, Y. utahana sp. nov., is described. It differs from the type and only known species, Y. tenuis, principally in its larger size and shorter exopods; it is the first description of this genus from outside the Burgess Shale. A new species of a stem-group lophotrochozoan from the Spence Shale, Wiwaxia herka sp. nov., possesses a palisade of dorso-lateral spines that are more robust and numerous than the type species of Wiwaxia, W. corrugata. Another notable taxon is Eldonia ludwigi from the Marjum Formation, which is interpreted as a primitive ambulacrarian (assigned to the cambroernids) and a new specimen of the ?cnidarian Cambrorhytium from the Wheeler Shale is illustrated.
\end{abstract}

\section{Introduction}

The soft-bodied and lightly skeletalized fossils of the Burgess Shale-type biotas have had a profound impact on our understanding of the major radiations of the early metazoans, an event colloquially referred to as the Cambrian "explosion" (e.g., Conway Morris, 1998; Marshall, 2006). To date, only three occurrences are especially prolific. These are the type locality in British Columbia, Canada (and adjacent outcrops, see Collins et al., 1983), the Chengjiang localities around Kunming, Yunnan, China (e.g., Chen and Zhou, 1997; Zhang et al., 2008), and Sirius Passet, Peary Land, North Greenland (e.g., Conway Morris and Peel, 1995, 2008; 2010; Budd, 2011; Daley and Peel, 2010; Ineson and Peel, 2011; Peel and Ineson, 2011). This is not to say that other localities do not have very considerable potential: most notable in this respect are faunas from the Emu Bay Shale of South Australia (e.g., Paterson et al., 2010, 2011; Edgecombe et al., 2011) and in South China both the Kaili deposits from Guizhou, (e.g., Zhao et al., 2003, 2005; Lin, 2006; Yang et al., 2011) and new assemblages (Guanshan, Xiaoshiba) adjacent to Kunming (e.g. Hu et al., 2010; Yang et al., 2013).

Although these localities rightly enjoy the lion's share of attention, in terms of present-day geography, the lower and middle Cambrian Burgess Shale-type faunas (broadly construed: Conway Morris, 1989; Butterfield, 1995) are widely distributed, with records from western Canada (e.g., Copeland, 1993;
Butterfield and Nicholas, 1996; Randell et al., 2005; Johnston et al., 2009; Caron et al., 2010; Kimmig and Pratt, 2015), eastern United States (e.g., Skinner, 2005; Schwimmer and Montante, 2007; Conway Morris and Peel, 2010), Russia (e.g., Repina and Okuneva, 1969; Friend et al., 2002; Ivantsov et al., 2005), Australia (e.g., Jago and Anderson, 2004; Ortega-Hernandez et al., 2010), Europe (e.g., Conway Morris and Robison, 1986; Chlupáč and Kordule, 2002; García-Bellido et al., 2011; Gámes Vintaned et al., 2011), and China (e.g., Steiner et al., 2012; Xiao et al., 2005; Zhang and Hua, 2005; Liu, 2013; Sun et al., 2013).

It remains the case, however, that in a significant number of these latter Burgess Shale-type localities, the quality of preservation may be impressive, but the range of material is relatively limited and has only been obtained as the result of intensive and protracted seasons of collecting. This applies, for example, to a series of localities in the western United States, most of which are in Utah. Outcrops in the Latham Shale (Gaines and Droser, 2002), Poleta Formation (English and Babcock, 2010), Pioche Formation (e.g., Webster et al., 2008), Spence Shale (e.g., Conway Morris and Robison, 1988; Liddell et al., 1997; Gaines and Droser, 2005; Garson et al., 2012), Wheeler Formation (e.g., Conway Morris and Robison, 1986; Gaines et al., 2005; Halgedahl et al., 2009; Stein et al., 2011), Marjum Formation (e.g., Gaines and Droser, 2010), and Weeks Formation (e.g., Bonino and Kier, 2010; Robison and Babcock, 2011; Lerosey-Aubril et al., 2013) have yielded a 
series of Burgess Shale-type fossils. These include non-trilobite arthropods, priapulids, sponges and chancelloriids, as well as several taxa, notably the medusiform Eldonia and cataphract Wiwaxia, whose systematic positions have been more contentious. To the existing literature on these localities scattered across the Great Basin (e.g., Rigby, 1983; Gunther and Gunther, 1981; Briggs and Robison 1984; Robison, 1991; Conway Morris and Robison, 1986, 1988; Rigby et al., 1997; Waggoner and Hagadorn 2004; Briggs et al., 2005; Cartwright et al., 2007; Halgedahl et al., 2009; Moore and Lieberman, 2009; Conway Morris and Peel, 2010; Gaines and Droser, 2010) we now add some significant new finds. These include an articulated specimen of a new species of Wiwaxia (Spence Shale), arthropods in the form of Dytikosicula desmatae gen. et sp. nov. (Marjum Formation), as well as specimens of ?Yohoia sp. and Yohoia utahana sp. nov. (Spence Shale), and a large specimen of Eldonia (Marjum Formation). In passing, we also draw attention to a specimen of the questionable cnidarian Cambrorhytium (Wheeler Formation).

\section{Methods}

Specimens were photographed with Canon 5D MkII and MkIII cameras (Canon U.S.A. Inc., Melville, NY) mounted on Leica MZ12.5 and MZ16 stereomicroscopes, either dry or under $70 \%$ ethanol, and in cross-polarized light using a ring light and/or low-angle illumination with polarizing filters, and a polarizing filter in front of the objective lens. For each specimen, several photographs were taken at different levels of focus and then stacked using Adobe Photoshop CS6 (Adobe Systems Inc., San Jose, CA) to ensure all parts of each specimen were in focus. For some larger specimens, a mosaic of photographs was taken and these were then merged using Photoshop (see Selden, 2014 for further details). Drawings were made using camera lucida attachments to the microscopes and digitized using iDraw 2.4 (www.indeeo.com).

\section{Systematic paleontology}

Specimens are housed in the University of Kansas Natural History Museum, Lawrence, Kansas (KUMIP prefix) and the Sedgwick Museum, University of Cambridge (SM prefix).

\author{
Phylum Arthropoda von Siebold, 1848 \\ Family Yohoiidae Henriksen, 1928 \\ Genus Yohoia Walcott, 1912
}

Type species._Yohoia tenuis Walcott, 1912.

Yohoia utahana new species

Figure 1.1-1.4

Diagnosis.-Relatively large (approximately $30 \mathrm{~mm}$ ), tergites 10-13 bear tergopleurae, expods short with large spines, and mostly covered by tergopleurae.

Description.-Large Yohoia, body length $30.9 \mathrm{~mm}$ (including telson, excluding great appendage); straight trunk; head shield with median smooth portion, and large lateral area with strongly curved margins divided into three regions. Anterior border of median part of head shield expanded slightly anteriorly, beyond procurved line (Fig. 1.1, 1.2). Pair of eyes situated anteriorly beyond anterior margin of head shield. Great appendage consisting of proximal element emerging from beneath anterior head shield between eyes, extending downwards not beyond lateral edges of head shield, followed by distal element extending upwards. Trunk of 13 segments, increasing in length from approximately $1.0 \mathrm{~mm}$ (1), through approximately $1.5 \mathrm{~mm}$ (5-9) to approximately $2.0 \mathrm{~mm}$ (11-13), and telson. Tergites show slight posterior imbrication. Tergopleura of tergite 1 lobate, narrower (transversely) than other tergites, partly covered by posterior margin of head shield. Tergopleurae 2-9 lobate, with recurved anterior margin, curved tip, procurved posterior margin (Fig. 1.1, 1.2). Curvature of anterior and posterior margins increases posteriorly, so tergopleurae of more posterior tergites appear more swept back. Tergopleura 10 with recurved anterior margin, short pointed posterior angle. Tergopleurae 11-13 narrower (transversely), with short sharply pointed posterior angles. Trunk limbs with exopod and endopodal rami. At least 6 endopods, associated with trunk segments 1-5, 8 (Fig. 1.3, 1.4); exopods on trunk segments 1-9, not seen on segments 10-13. Endopods slender, at least distally where seen protruding from beneath head shield or tergopleurae, tapering distally. Exopods appear as fan of stout bristles, connected by organic material (?setules), curving backwards and downwards, extending only slightly beyond margins of tergopleurae. Telson spatulate, lineations on surface, straight posterior margin bearing zigzag pattern of short spines.

Holotype.-KUMIP 357406, only known specimen (collected by $\mathrm{PMJ})$, part and counterpart.

Etymology.-After Utah, the state in which the specimen was found.

Occurrence.-Spence Shale Member, Langston Formation (Hintze, 1988, Chart 15), lower Middle Cambrian, polymerid Glossopleura Zone (Robison, 1976). Locality is about $35 \mathrm{~m}$ above base of Spence Shale, Miner's Hollow, Wellsville Mountain, Box Elder County, Utah.

Remarks.-Terminology follows Haug et al. (2012). It is not straightforward differentiating morphology from abiogenic marks in the matrix, such as with a scattering of darker patches, particularly near the anterior of the specimen. A suboval patch near the apex of the head shield resembles an eye. However, in cross-polarized light, the putative eye shows a slightly different coloration, indicating that the suboval patch is matrix. Similarly, matrix patches align with the endopods but these, too, are not thought to be part of the animal.

The body is laterally compressed. Anteriorly, however, the head region has rotated longitudinally. Previous reconstructions of Yohoia (Whittington, 1974; Haug et al., 2012) show the eyes to be near the top of the head shield, adjacent to the base of the lateral area of the head shield. In this specimen, the eye position is similarly adjacent to the base of the lateral area of the head shield, but the head shield extends further dorsally from the eye 


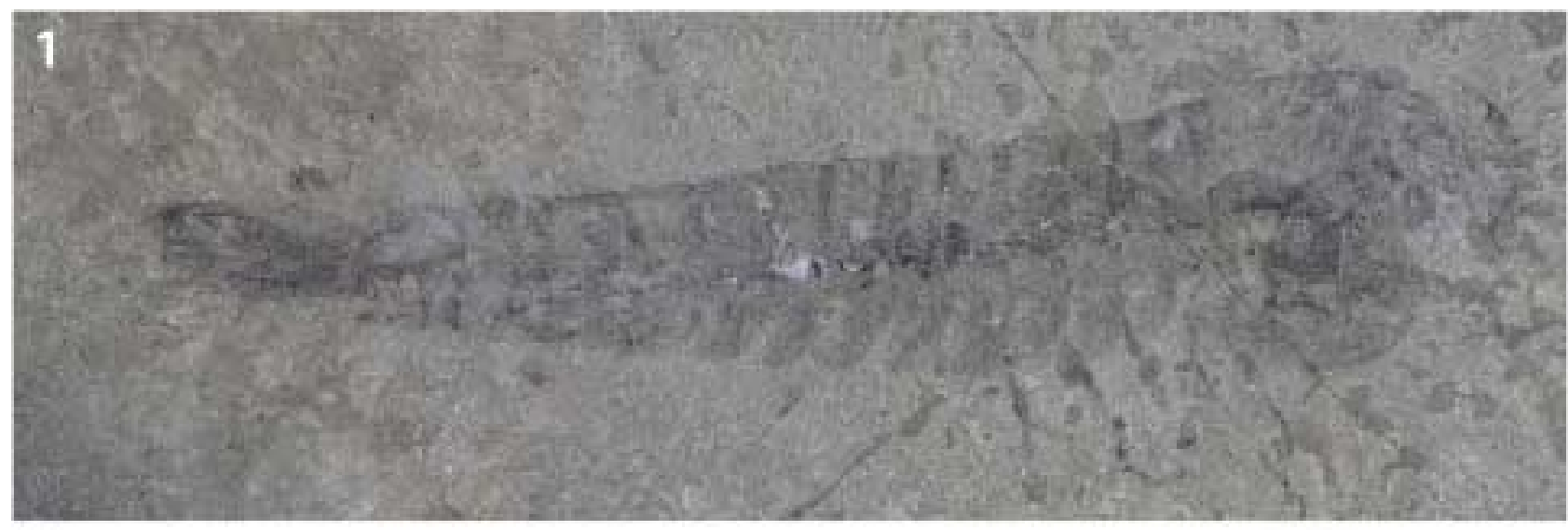

2
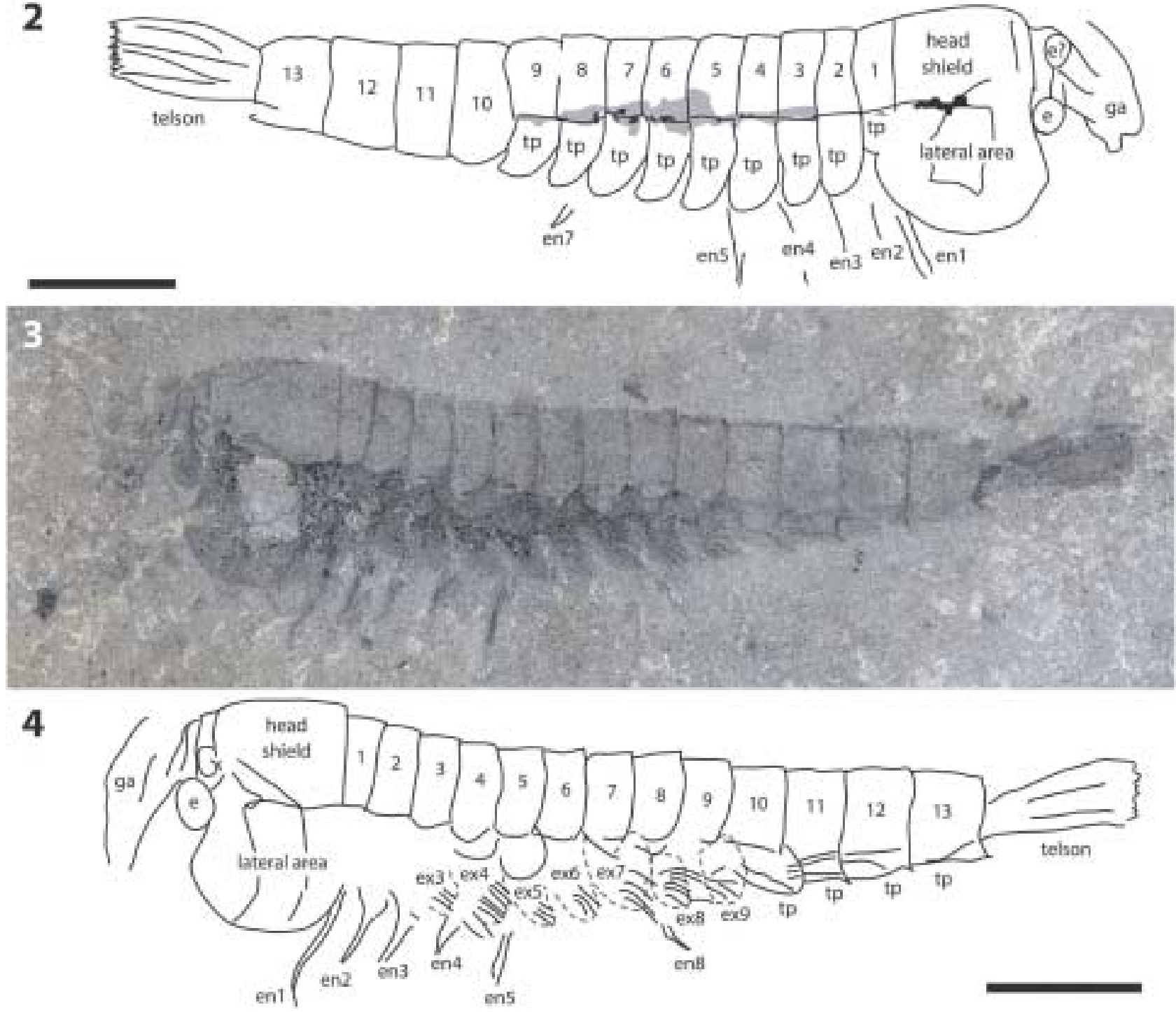

Figure 1. Yohoia utahana sp. nov., holotype, KUMIP 357406. (1) photograph of part; (2) interpretative camera-lucida drawing of part; (3) photograph of counterpart; (4) interpretative camera-lucida drawing of counterpart. e, eye; ex1, ex2, etc. exopods; en1, en2, etc., endopods; ga, great appendage; tp, tergopleura. Grey areas indicate possible gut trace; black shows black particles within possible gut (Fig. 1.2). Dashed lines on Figure 1.4 indicate outline of darker color representing organic material between exopod spines. Scale bars represent $5 \mathrm{~mm}$.

than would be the case if it were strictly a lateral compression. At the opposite end of the animal, the telson also presents a dorso-ventral aspect, similarly suggesting a degree of rotation.
The body is straight with neither curvature nor a distinct bend which would indicate a tail region. In life, however, it was clearly flexible because adjacent tergites imbricate. Cephalic 
appendages include a poorly preserved great appendage and a pair of eyes. With respect to the former the great appendage is poorly preserved, but appears to show a downward part emerging from the anterior of the head between the eyes, and beyond this an upward-sweeping part (the claw element). In the case of the eyes one is located between the great appendage and the head shield; the other eye is less obvious but on the part is superimposed on the base of the great appendage (Fig. 1.1, 1.2). Scattered black patches along the trunk (most obvious on segments 3-9) may be remains of the gut; the line of these coincides with the junction between the main part of each tergite and its tergopleura (Fig. 1.1, 1.2). A similar line of dark patches can be seen in the Yohoia specimens figured by Haug et al. (2012; fig. 3).

Interpretation of the tergopleurae and exopods is problematic. The part (Fig. 1.1, 1.2) shows lateral tergopleurae which extend at least the same distance from their junction with main tergite as the width of the latter. In contrast, in the type species the tergopleurae are relatively shorter than the large, flap-like structures that extend beyond the tergite edges and have been interpreted as exopods (Whittington, 1974; Haug et al., 2012). On the counterpart (Fig. 1.3, 1.4) radiating lines resemble the fringing setae of the exopods, but they are much sparser and stouter. Moreover, rather than forming a fringe they are almost completely covered by the tergopleurae. Thus, in the new species, the exopods are shorter than in $Y$. tenuis (see Haug et al., 2012, fig. 9). In $Y$. utahana, the tips of the tergopleurae do not extend beyond the lateral edge of the head shield, as do the ends of the radiating lines. The tergopleurae (in the part; Fig. 1.1, 1.2) seem, therefore, to be real, whereas the underlying radiating lines (in the counterpart, Fig. 1.3, 1.4) likely represent exopodal spines. On the counterpart (Fig. 1.3, 1.4), the matrix shows a darker hue between the exopodal spines (outlined in dashed lines on the drawing), which possibly represents organic materialperhaps masses of setules - connecting the exopodal spines.

Compared with the type and only known species of Yohoia (Y. tenuis Walcott, 1912), this is larger, with a body length of $30.9 \mathrm{~mm}$. Length of tergites 3-5 (11 of Haug et al., 2012) is $4.2 \mathrm{~mm}$, length of the head shield (12 of Haug et al., 2012) is $4.6 \mathrm{~mm}$. Plotting 11/12 (Fig. 2) on the graph of similar measurements for $Y$. tenuis (Haug et al., 2012, fig. 2) shows $Y$. utahana to lie well beyond the scatter of points, at more than twice the mean for both measurements of the type species. The lateral areas of the head shield show strongly curved margins, in which respect it differs from the type species, in which these lateral areas are subquadrate (Whittington, 1974, text-fig. 2; Haug et al., 2012). As in Y. tenuis, the lateral area is divided into three parts, and the trunk consist of 13 segments and a telson which is almost indistinguishable from that of $Y$. tenuis (Whittington, 1974).

Related genera (Stein et al., 2013) from the Lower Cambrian Chengiang biota of China include Fortiforceps Hou and Bergström, 1997, which has somewhat similar exopods but lacks tergopleurae and has 20 tergites, and Jianfengia Hou, 1987, which has even more (22) tergites. On the other hand Haikoucaris Chen, Waloszek and Maas, 2004 has the same number of postcephalic tergites as Yohoia (13) and possibly similar exopods (albeit on all trunk segments), but lacks tergopleurae and has a distinct telson. Yohoia differs from all

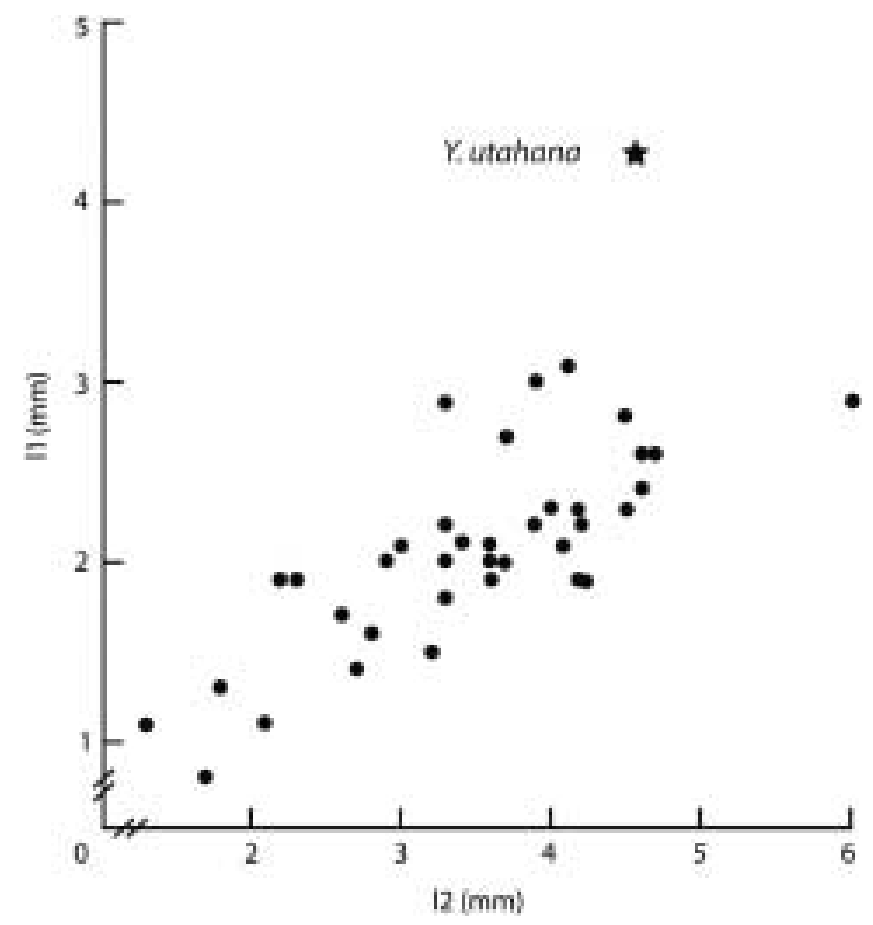

Figure 2. Scatterplot of lengths of tergites three to five (11) versus length of head shield (12) of: Yohoia tenuis Walcott, 1912, and $\star$ Yohoia utahana sp. nov. Yohoia tenuis data from Haug et al. (2012, fig. 2).

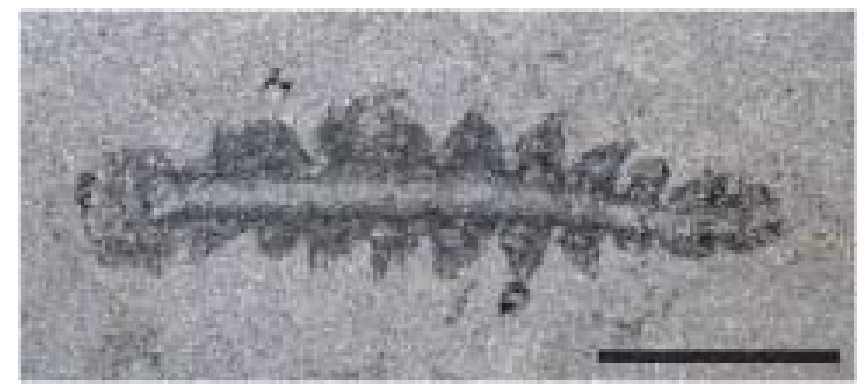

Figure 3. ?Yohoia sp., SM X.50206; photograph under ethanol. Scale bar represents $5 \mathrm{~mm}$.

of these related genera in its distinctive head shield with the large, tripartite, lateral area, and spatulate telson composed of a single plate.

\section{?Yohoia species indeterminate} Figure 3

Description.-Single specimen occurs in dorso-ventral aspect. Most obvious feature is trunk, with at least nine segments, and prominent tergopleurae (Fig. 3). Largest of these at mid-point, and decrease markedly in size toward the presumed posterior. Broad central strand may represent gut trace. It has slight relief, and may be sediment-filled. Alternatively (considering Yohoia is not known to have a sediment-filled gut), the specimen may have split at level of tergopleurae but below level of arched dorsum, revealing matrix beneath. Both ends of specimen indistinct, but presumed anterior (head shield) approximately quadrate. Opposite end smaller and appears to be approximately circular. No appendages preserved. 
Material.-SM X.50206, collected by PMJ, part only.

Occurrence.-Spence Shale Member, Langston Formation, (Hintze, 1988, Chart 15), lower middle Cambrian, polymerid Glossopleura Zone (Robison, 1976). Locality is approximately $16 \mathrm{~m}$ above base of Spence Shale, as float, Miner's Hollow, Wellsville Mountain, Box Elder County, Utah.

Remarks.-Attribution to Yohoia (see Whittington, 1974) is provisional. Apart from size, its principal similarities are the prominent tergopleurae, and possibly the head-shield. Unlike Yohoia, however, the tergopleurae are prominent to the last (visible) trunk segment

\section{Genus Dytikosicula new genus}

Diagnosis.—As for the species.

Type species.—Dytikosicula desmatae new species.

Etymology.-Based on the Greek west (dytikos) and small dagger (sicula), and is a combined reference to both the geographical area and the recurved paratergal extensions.

Remarks.-This new taxon is similar to Dicranocaris (Briggs et al., 2008). Phylogenetic relationships of Cambrian arthropods
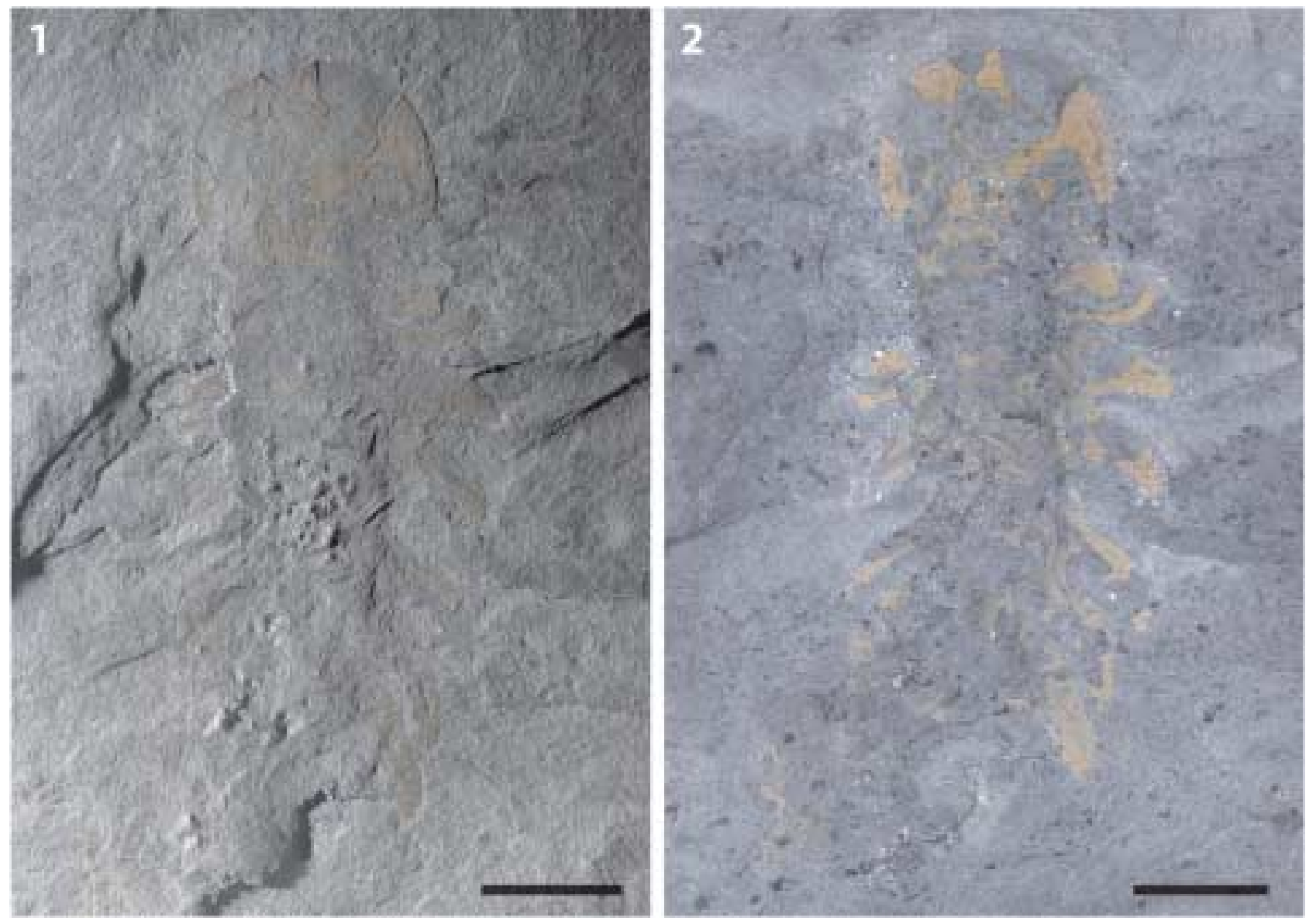

Figure 4. Dytikosicula desmatae gen. et sp. nov., holotype, SM X.50203. (1) photograph dry in low-angle light; (2) photograph under ethanol. Scale bars represent $5 \mathrm{~mm}$.

are not fully resolved but Dicranocaris appears to be a megacheiran (Ortega-Hernández et al., 2013; see also Hendricks and Lieberman, 2008).

\section{Dytikosicula desmatae new species \\ Figures 4.1-4.2, 5.1-5.2}

1981 ?Molaria-like trilobitomorph, Gunther and Gunther, pl. 48B.

1991 ?Alalcomenaeus cf. cambricus (Simonetta); Robison, p. 86, fig. 7.10 .

2008 ?Dicranocaris guntherorum Briggs et al., p. 245, figs 5.4-9 [non figs. 5.1-3].

Diagnosis.-Subcircular head shield and trunk with at least six tergites, all with prominent pleurae. It differs from Dicranocaris by trunk segment one bearing pleura, and pleurae more arcuate. Head shield similar, but dorsal outline more circular.

Description.-Single specimen (Figs. 4, 5) preserved in dorsal aspect, lacks posterior section. Head shield suboval in outline, with smooth margins and gently concave posterior margin abutting first thoracic segment. No evidence for eyes. Trunk undifferentiated, but bears six rather prominent pleural 


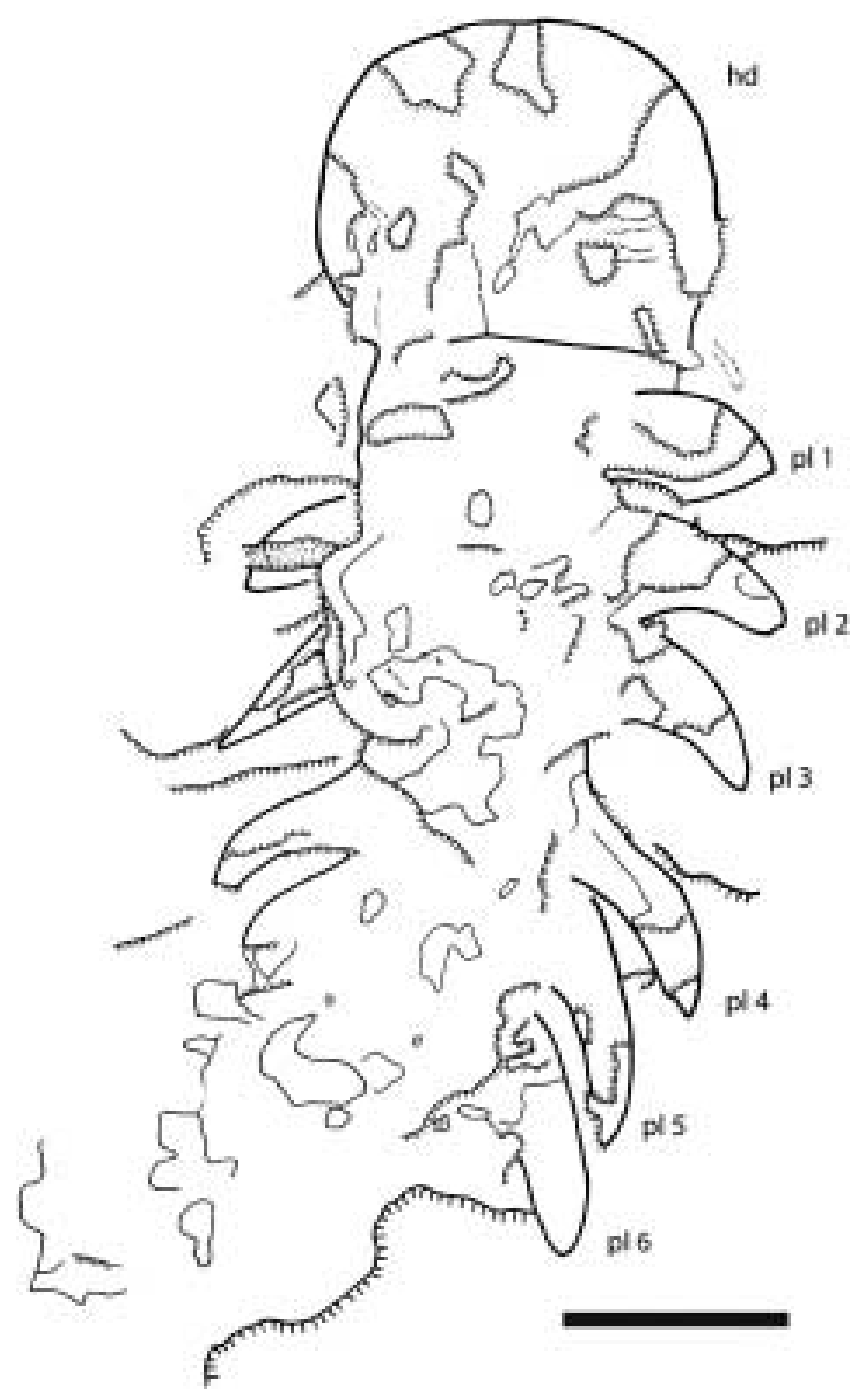

Figure 5. Interpretative camera-lucida drawing of Dytikosicula desmatae gen. et sp. nov., compare Figure 4. hd, head shield; pl 1, pl 2, etc., pleurae 1-6. Scale bar represents $5 \mathrm{~mm}$.

extensions, quite strongly recurved posteriorly and well separated. Posterior end incomplete. No appendages preserved.

Holotype.-SM X.50203, holotype and only known specimen, part only. Specimen originally collected by Robert Drachuk, and donated by Charlie Magovern.

Etymology.-Refers to the proposed link (Greek, desmos, bond or chain) to other Cambrian megacheirans.

Occurrence.-Marjum Formation, middle Cambrian. Locality is west of Delta, House Range, Utah.

Remarks.-Specimen shows characteristic Burgess Shale-type preservation (e.g. Briggs et al., 2008). Otherwise parts of the fossil have a brownish mineral adhering which may represent the original skeleton, apparently uncalcified. Associated with part of the thorax are granular areas, probably representing diagenetic mineral growth (?pyrite). These are not obviously consistent with any soft-part anatomy, but may have resulted from decaying tissue.

This new taxon is most similar to the megacheiran Dicranocaris guntherorum Briggs et al., 2008, best known from the Wheeler Formation but is also recorded from the Marjum Formation. Detailed comparisons are hindered because the best preserved specimen of $D$. guntherorum is more complete than the sole specimen of $D$. desmatae, and is buried at an oblique angle in comparison to the dorso-ventral attitude of the specimen described here. The most obvious difference is that whereas in D. guntherorum the pleural extensions of the trunk are limited to segments 2 to 5 , in $D$. desmatae each of the preserved segments bears pleura. In addition and making allowances for the different angles of burial, the head of D. desmatae appears to be somewhat more circular. Deciding whether Dytikosicula desmatae is a distinct taxon, or better interpreted as another species of Dicranocaris is to some extent a matter of judgement. Generic distinction, however, is warranted not only by the differences noted, but also the conspicuously larger size of the holotype. In this context it is tentatively suggested that other material (albeit from the Wheeler Formation) and attributed questionably to D. guntherorum by Briggs et al. (2008; figure 5.4-9; see also Gunther and Gunther, 1981; Robison, 1991) not only falls into the same size range of D. desmatae but may be better accommodated in this taxon. Thus despite poor preservation these specimens (all in lateral view) show some evidence for a pleuron on the first trunk segment (see also Gunther and Gunther, 1981, pl. 48; the precise interpretation of these structures diverged amongst the authors contributing to Briggs et al. (2008)).

It is also worth noting a possible relationship to the arthropod Serracaris lineata Briggs, 1978, which is known only from the Lower Cambrian Kinzers Formation of Pennsylvania. All specimens of this taxon are incomplete, but available material consists of an elongate trunk consisting of at least fifteen tergites with recurved extensions. The most obvious differences are that in Serracaris these tergal extensions on either side appear to be double. In addition, one segment towards the anterior end has conspicuously larger extensions, although there they appear to have been single. Briggs (1978, Pl. 1, fig. 4) drew attention to a possible anterior carapace. Because of its unique occurrence he regarded it, however, as probably fortuitous. It does, however, have some similarity to the head shield of Dytikosicula, but in Serracaris it appears proportionally larger and possibly wider. Although the posterior end of the unique specimen of $D$. desmatae is not preserved, Briggs et al. (2008) drew attention in D. guntherorum to "the unique morphology of the telson" (p. 245) with its terminal bifurcation. Although these authors made no comparison, Serracaris also possesses a bifurcate telson (Briggs, 1978). Serracaris is, of course, stratigraphically somewhat older than Dytikosicula. From the Eldon Formation of British Columbia Briggs (1978, text fig. 2a, b) described a more nearly contemporaneous form to $D$. desmatae as Serracaris?. The unique specimen is poorly preserved, and appears to have had more spinose tergal projections.

\section{Stem-group Lophotrochozoa}

Remarks.-Current consensus regards the wiwaxiids as having a molluscan affinity (e.g. Yang et al., 2014). Our material throws no 
further light on this question, and we prefer to take a more agnostic view of their wider relationships, placing them within the lophotrochozoans but not shoe-horning them into a specific phylum.

Family Wiwaxiidae Walcott, 1911a;

Remarks.-Wiwaxiids are best known from articulated material of Wiwaxia corrugata (Matthew, 1899) from the Phyllopod Bed of the Burgess Shale (Conway Morris, 1985). Also occurring in this deposit in moderate abundance are isolated sclerites (and rarely partial associations), detached from the cataphract scleritome either by deciduous action or upon death and post-mortem scattering (see also Butterfield, 1990; Mankiewicz, 1992). Sclerites are also known from the Lower and Middle Cambrian of northwestern Canada (e.g. Butterfield and Nicholas, 1996), South China (e.g. Y-L. Zhao et al., 1994, 2005; Harvey et al., 2012; Sun et al., 2014; Yang et al., 2014; F-C. Zhao et al., 2015), Utah (Conway Morris and Robison, 1988), Australia (Porter, 2004), Czech Republic (Fatka et al., 2011) and Siberia (Ivantsov et al., 2005). These records collectively indicate that the individual sclerites were probably robust and relatively resistant to decay. In contrast, articulated wiwaxiids are very rare. Apart from the Burgess Shale examples (Conway Morris, 1985) and recent discoveries from the Xiaoshiba Lagerstätte (Yang et al., 2014) and the Kaili Formation (Zhao et al., 1994, 2005, Pl. II, fig. 2; also Sun et al., 2013, fig. 6) in China, our report is the only known occurrence of an articulated specimen from Laurentia.

Genus Wiwaxia Walcott, 1911a Type species.-Wiwaxia corrugata (Matthew, 1899).
Wiwaxia herka new species

Figure 6.1-6.8

Diagnosis.-A wiwaxiid with a prominent palisade of recurved and stout dorso-lateral spines. Differs from type species in larger number of spines and their degree of robustness.

Description.-Single articulated specimen (Fig. 6.1, 6.2) preserved in approximately lateral view, shows a fairly pronounced dorso-ventral curvature (cf., Conway Morris, 1985, figs. 82, 83, 88). Most obvious feature is palisade of dorso-lateral spines. These are quite stout, posteriorly recurved, closely spaced. Those on the right-hand side (in the part) are clearest, with a total of 13 visible. Near the anterior end, a few spines of the opposite side are visible at a lower level. Three anterior-most spines are somewhat shorter (about half the length of others), whereas remainder longer and sub-equal length, except at posterior where again last one or two shorter. Remaining sclerites, that mantled dorsal and lateral regions of the body, only moderately well preserved, but components of the lateral and ventro-lateral series are identifiable. In addition to the articulated specimen, six isolated sclerites are available. Based on the characteristic recurved shape, three (KUMIP 286300, 286302) are identified as ventro-lateral (equivalent to siculate; see Conway Morris and Peel, 1995 [Fig. 6.3, 6.7, 6.8]). Another two sclerites (KUMIP 286300, 286301), one of which is poorly preserved, are more elongate and probably represent lateral ( = cultrate) sclerites (Fig. 6.4, 6.5). Finally, one sclerite (KUMIP 286301) may be from the dorsal region (Fig. 6.6).
Holotype.-KUMIP 287449, holotype, part and counterpart (Fig. 6.1, 6.2), collected by Glade Gunther. Paratypes, KUMIP 286300 (part with two sclerites, counterpart with opposite side of ?lateral sclerite only) (Fig. 6.3-6.5), 286301 (Fig. 6.6), 286302 (part and counterpart) (Fig. 6.7, 6.8), donated by Lloyd Gunther.

Etymology.-From herka (Greek, fence), in reference to the palisade of spines.

Occurrence.-Spence Shale Member, Langston Formation (Hintze, 1988, Chart 15), lower Middle Cambrian, polymerid Glossopleura Zone (Robison, 1976). Locality is approximately $3 \mathrm{~m}$ below top of Spence Shale, south side of Antimony Canyon on west side of Wellsville Mountain; NW1/4 sec. 31, T. $10 \mathrm{~N}$., R. 1 W.; approximately $4 \mathrm{~km}$ north of Brigham City, Box Elder County, Utah. Other biota from the same locality, mostly collected by members of the Lloyd Gunther family, include trilobites Amecephalus idahoense (Resser, 1939a), Athabaskia wasatchensis (Resser, 1939b), Glossopleura gigantea ? Resser, 1939a, Glossopleura sp., Kootenia mendosa Resser, 1939a, and Zacanthoides idahoensis Walcott, 1908; other arthropods Meristosoma paradoxum Robison and Wiley, 1995, Hurdia indet. sp. (Daley et al., 2013) and an undetermined taxon with large axial spine on rear shield; undetermined articulate brachiopods; echinoderms Ctenocystis utahensis Robison and Sprinkle, 1969, and Gogia sp. nov.; a hemichordate (see Loduca et al., 2013) Yuknessia simplex Walcott, 1919; hyolith Hyolithes carinatus Babcock and Robison, 1988; sponge Vauxia gracilenta? Walcott, 1920; worms Ottoia prolifica Walcott, 1911a, and Selkirkia sp.; other animal taxa, Eldonia ludwigi Walcott, 1911b, and Scenella sp.; large coprolites (cf. Conway Morris and Robison, 1988, fig. 32); and algae Marpolia spissa Walcott, 1919.

Remarks.-Erection of new species Wiwaxia herka is based on a single articulated specimen, seems justified on account of the distinctiveness of its dorso-lateral spines. In contrast to W. corrugata (Conway Morris, 1985) spines are more densely arrayed (approximately 12 versus an average of approximately 8 ) and less elongate. On the unproven assumption that the isolated sclerites (Fig. 6.3-6.8) derive from the same species, the ventro-lateral ones appear similar to those of $W$. corrugata, whereas the ?lateral and ?dorsal sclerites appear to be more elongate. $W$. herka is evidently closely related to $W$. corrugata, but differs more obviously from other lower Cambrian taxa from China (Zhao et al., 1994; Yang et al., 2014) in being substantially larger and possessing spines (also absent in juvenile W. corrugata: Conway Morris 1985).

This new species confirms the basic arrangement of the wiwaxiid scleritome, but does not throw further light on their phylogenetic position within the lophotrochozoans. One approach is to treat wiwaxiids as stem-group annelids. This is on the dual supposition of the similarities of the sclerite microstructure to annelidan chaetae (Butterfield, 1990; see also Conway Morris and Peel, 1995) and the inferred transformation of the scleritome into parapodial bundles capable of locomotion and defense (Conway Morris and Peel, 1995; Struck, 2011). Arguments, especially on the nature of the radula-like mouth- 

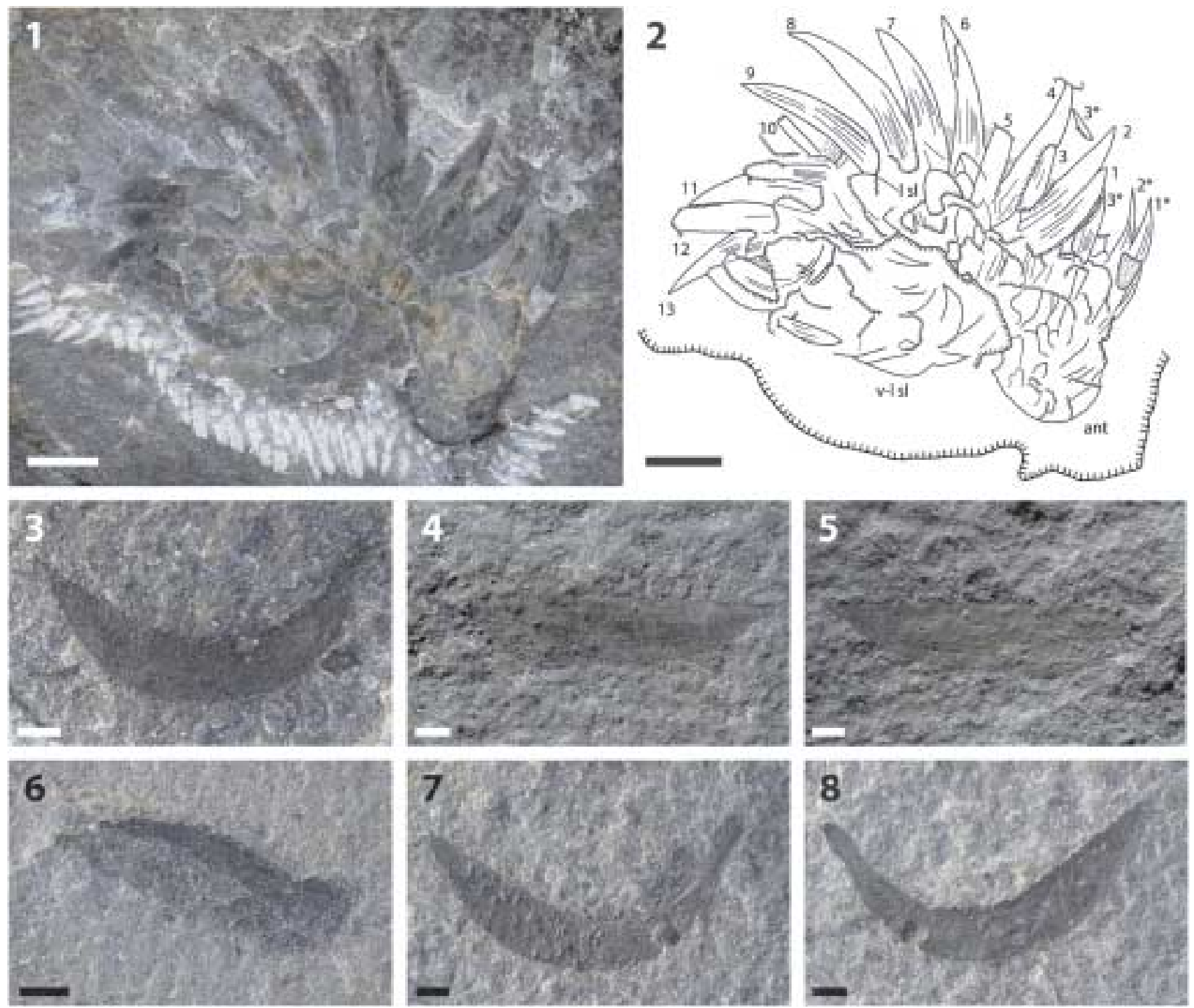

Figure 6. Wiwaxia herka sp. nov. (1) holotype, KUMIP 287449; (2) holotype, interpretative camera-lucida drawing, compare Figure 6.1 Fine lines represent striations on sclerites; other lines partial outlines of compressed sclerites. Hachure on lower side is edge of excavated sediment. ant, anterior; $1 \mathrm{sl}$, lateral sclerites; v-1 sl, ventro-lateral sclerites. Dorso-lateral spines numbered consecutively from anterior; numbers with asterisks refer to left side, others more complete series on right side; (3-5) KUMIP 286300: (3) isolated ventro-lateral sclerite (part only); (4) isolated ?lateral sclerite, part; (5) isolated ?lateral sclerite, counterpart; (6) KUMIP 286301 isolated ?dorsal sclerite (part only); (7) KUMIP 286302 isolated ventro-lateral sclerite, part; (8) KUMIP 286302, isolated ventro-lateral sclerite, counterpart. All photographs taken dry under cross-polarized illumination. Scale bars represents $5 \mathrm{~mm}(\mathbf{1}, \mathbf{2}), 1 \mathrm{~mm}(\mathbf{3}-\mathbf{8})$.

parts (Smith, 2012) and similarities to Odontogriphus (Caron et al., 2006) on the other hand point to a molluscan affinity (see also Smith, 2014). By itself, W. herka can add nothing material to this discussion, but it is worth emphasizing that if the wiwaxiids belong to a stem-group identified as the halwaxiids (Conway Morris and Caron, 2007) then shoe-horning them into a given phylum may serve to obscure how crucial anatomical transitions were achieved among which end-results are the setae of annelids (and brachiopods) or radula of mollusks.

\section{Superphylum Ambulacraria Metschnikoff 1881 Stem-group Cambroernids}

Remarks.-The cambroernids is an un-ranked informal stem group (Caron et al., 2010).
Family Eldoniidae Walcott, 1911b Genus Eldonia Walcott, 1911b

Type species.—Eldonia ludwigi Walcott, 1911b.

Eldonia ludwigi Walcott, 1911b

Figure 7.1-7.2

Description.-New specimen, part and counterpart, incomplete with slightly more than half disc preserved. Maximum width approximately $80 \mathrm{~mm}$. Principal features (Fig. 7) visible are part of gut (and associated coelomic cavity) and disc. Latter consists of two fairly distinct regions. Inner zone traversed by series of widely spaced radial lines, which are probably on surface of disc. Outer region bears semi-continuous groove (in part) and 
otherwise subdued concentric wrinkles. Half of disc, which might have shown the feeding apparatus, not preserved.

Material.-SM X.50204.1 (part) and SM X.50204.2 (counterpart), collected by Paul Jamison.

Occurrence.-Middle part of Marjum Formation, mid-middle Cambrian, Ptychagnostus punctuosus Zone. Locality is Marjum Pass, House Range, Millard County, Utah.

Remarks.-Specimen from the same stratigraphic horizon was described by Conway Morris and Robison (1988, figs. 28, 29). To first approximation new specimen is similar, but preserves outer parts of the disc more clearly.

The medusiform eldoniids (and rotadiscids) are a characteristic component of Burgess Shale-type faunas. In addition to their type occurrence in the Burgess Shale (Walcott, 1911b; Durham, 1974; Friend, 1995), this group is recorded from other Lower (e.g., Chen et al., 1995; Chen and Zhou, 1997) and Middle Cambrian localities in China (Zhao and Zhu, 1994; Dzik et al., 1997), Siberia (Friend et al., 2002), Poland (Masiak and Zylińska, 1994), and Utah (Conway Morris and Robison, 1988) Taxonomic affinities of the eldoniids have remained controversial (e.g., Zhu et al., 2002). One suggestion has been to link them to the lophophorates (e.g., Dzik et al., 1997). More popular has been to pursue a relationship either to the echinoderms (e.g., Friend, 1995) or a more specific proposal that they are actual holothurians, an idea that stems back to the time of C.D. Walcott (e.g., Clark, 1912) and has received recurrent support (e.g., Durham, 1974; Hou and Bergström, 2003). The description of the related Herpetogaster collinsi from British Columbia (Caron, Conway Morris and Shu, 2010; see also Caron et al., 2010) suggests, however, that this taxon, along with Eldonia and Phlogites, are stem-group ambulacrarians forming an informal group known as the cambroernids that lies close to the echinoderm-hemichordate divergence.

\section{Wider significance}

While these finds augment existing knowledge of otherwise rare taxa, it is worth reviewing some wider implications of this work. First, as noted, Dytikosicula desmatae gen. et sp. nov. appears to be a megacheiran, closely related to Dicranocaris guntherorum. In the wider context of Cambrian arthropod evolution (e.g., Budd and Telford, 2009; Edgecombe, 2010) the overall diversity of known taxa is striking, and reports of more poorly preserved material (e.g., Halgedahl et al., 2009; Johnston et al., 2009; Caron et al., 2010) that in at least some cases represent new forms (e.g. Legg, 2013) suggest that our documentation of arthropod morphospace is incomplete. Thus, in the context of the description of Dytikosicula and its phylogenetic proximity to Dicranocaris, this indicates a relatively densely occupied area of morphospace, but a cursory glance at other Cambrian megacheirans (see Hendricks and Liebermann, 2008) suggests otherwise a considerable disparity. So too the identification of a new species of Yohoia hints at another more densely populated area of arthropod morphospace.

While the collection of Burgess Shale-type fossils from Middle Cambrian localities in the western United States has proved to be a relatively slow process, these new finds serve two useful purposes. First, they confirm that the diversity of these faunas remains incompletely documented. Second, they reinforce the notion of a Burgess Shale-type fauna that arguably is typical of Cambrian shelf seas, although this is not to dispute environmental controls on the make-up of particular assemblages. In general, however, the Burgess Shale-type faunas differ more in the details rather than general aspect. Although the majority of assemblages were deposited in offshore, even deeper water, and in conditions of low oxygen (e.g., Gaines and Droser, 2010), shallower water locales are also known (e.g., Copeland, 1993; Schwimmer and Montante, 2007; Gehling et al., 2011; see also Masiak and Zylińska, 1994). Collectively, these confirm a broad faunal identity characterized by arthropods, sponges, priapulids as well as eldoniids (and less frequently groups such as chordates, polychaetes and vetulicolians), along with a variety of typical Cambrian shelly taxa (trilobites, hyoliths,

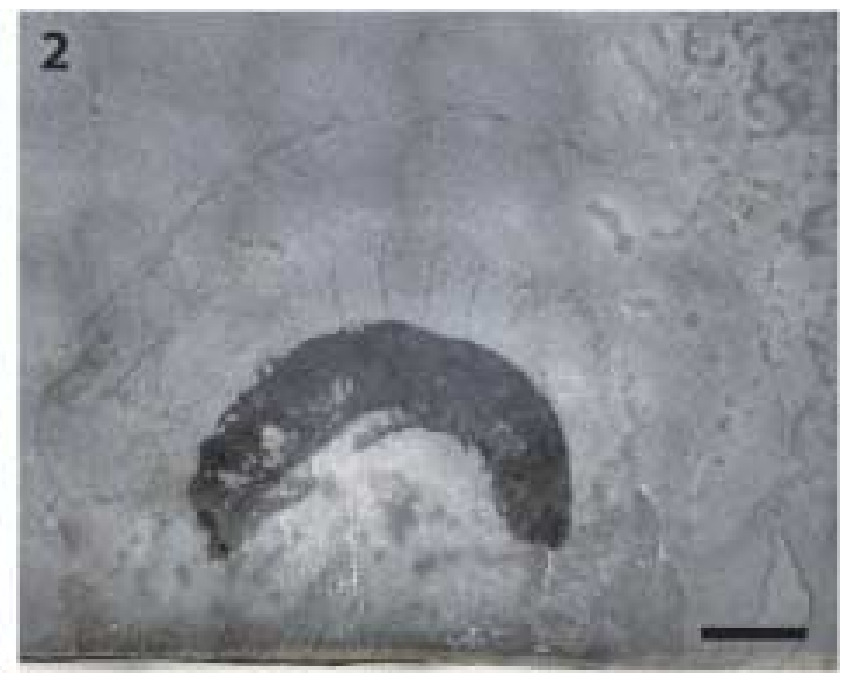

Figure 7. Eldonia cf ludwigi Walcott 1911, SM X.50204.1; (1) photographed dry in low-angle light; (2) photographed under ethanol. Scale bars represent $10 \mathrm{~mm}$. 


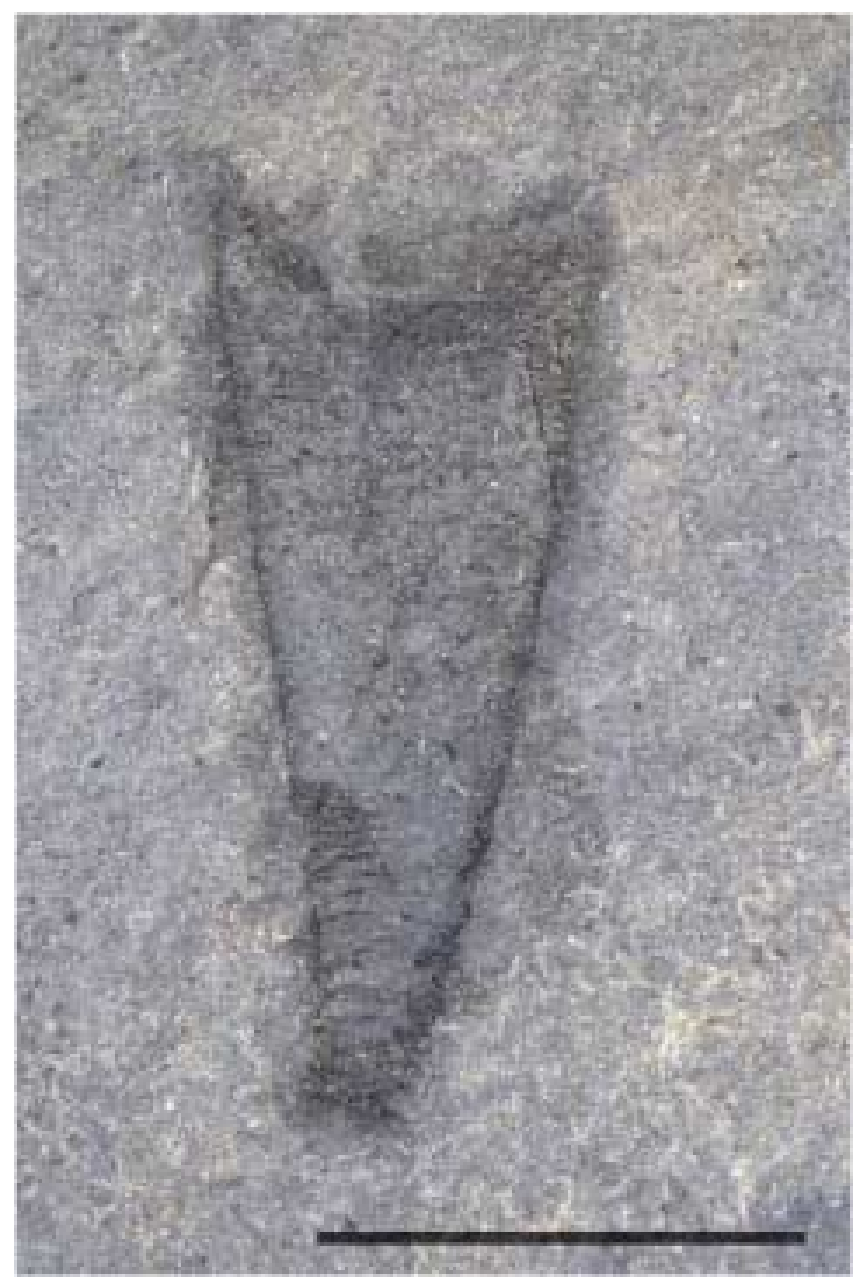

Figure 8. Cambrorhytium sp., SM X.50205.2. Scale bar represents $5 \mathrm{~mm}$.

brachiopods). Despite this common identity, subtle distinctions may ultimately reveal paleoenvironmental controls that may in turn refine our understanding of the ecological preferences of at least some taxa. A useful test case involves the arthropod Marrella. Known from an incomplete specimen from the Lower Cambrian Balang Formation of Hunan (Liu, 2013) and slightly more abundantly from the lower Middle Cambrian Kaili FossilLagerstätte of Guizhou (Zhao et al., 2003), prior to these reports Marrella was effectively known only from the Phyllopod bed of the Burgess Shale (Whittington, 1971) and immediately adjacent areas (García-Bellido and Collins, 2006), where it occurs in extraordinary abundance (e.g. García-Bellido and Collins, 2006; Caron and Jackson, 2008). It remains conjectural what specific environmental conditions favor the occurrences of Marrella, or indeed other highly sporadic occurrences in the Burgess Shaletype faunas, such as the annelids, chordates, or halkieriids.

\section{Conclusions}

This report augments our knowledge of Cambrian arthropods, notably in the form of Yohoia utahana sp. nov. and Dytikosicula desmatae gen. et sp. nov., and illustrates a new species of Wiwaxia. It also amplifies the occurrences of Eldonia. Finally, we also note briefly a specimen (collected by PMJ) of the tubicolous ?cnidarian Cambrorhytium (see Conway Morris and Robison, 1988) from the upper Wheeler Shale (Fig. 8) of the Drum Mountains, Millard County, Utah. The specimen (part and counterpart) is relatively small (approximately $1 \mathrm{~cm}$ ) and at its proximal end shows relatively coarse growth lines (Fig. 8). No associated soft parts are evident.

\section{Acknowledgments}

We thank Sandra Last and Vivien Brown for technical assistance, and Martin Smith for a review of the manuscript, and referees Allison Daley and Diego Garcia-Bellido. We also thank Charlie Magovern for the gift of the holotype of Dytikosicula desmatae.

\section{References}

Babcock, L.E., and Robison, A., 1988, Taxonomy and paleobiology of some Middle Cambrian Scenella (Cnidaria) and hyolithids (Mollusca) from western North America, The University of Kansas Paleontological Contributions, Paper 121, p. 1-22.

Bonino, E., and Kier, C., 2010. The back to the past museum guide to trilobites: Lecco, Italy, Casa Editrice Marna, 495. p.

Briggs, D.E.G., 1978, A new trilobite-like arthropod from the Lower Cambrian Kinzers Formation, Pennsylvania: Journal of Paleontology, v. 52, p. 132-140.

Briggs, D.E.G., Lieberman, B.S., Halgedahl, S.L., and Jarrard, R.D., 2005 A new metazoan from the Middle Cambrian of Utah and the nature of the Vetulicolia: Palaeontology, v. 48, p. 681-686.

Briggs, D.E.G., Lieberman, B.S., Hendricks, J.R., Halgedahl, S.L., and Jarrard, R.D., 2008, Middle Cambrian arthropods from Utah: Journal of Paleontology, v. 82, p. 238-254.

Briggs, D.E.G., and Robison, R.A., 1984, Exceptionally preserved nontrilobite arthropods and Anomalocaris from the Middle Cambrian of Utah: The University of Kansas Paleontological Contributions, v. 111, p. 1-23.

Budd, G.E., 2011, Campanamuta mantonae gen. et sp. nov., an exceptionally preserved arthropod from the Sirius Passet fauna (Buen Formation, Lower Cambrian, North Greenland): Journal of Systematic Palaeontology, v. 9, p. 217-260.

Budd, G.E., and Telford, M.J., 2009, The origin and evolution of arthropods: Nature, v. 457, p. 812-817.

Butterfield, N.J., 1990, A reassessment of the enigmatic Burgess Shale fossil Wiwaxia corrugata (Matthew) and its relationship to the polychaete Canadia spinosa Walcott: Paleobiology, v. 16, p. 287-303.

Butterfield, N.J., 1995, Secular distribution of Burgess Shale-type preservation: Lethaia, v. 28, p. 1-13.

Butterfield, N.J., and Nicholas, C.J., 1996, Burgess Shale-type preservation of both non-mineralizing and 'shelly' Cambrian organisms from the Mackenzie Mountains, Northwestern Canada: Journal of Paleontology, v. 70, p. 893-899.

Caron, J.-B., Conway Morris, S., and Shu, D., 2010, Tentaculate fossils from the Cambrian of Canada (British Columbia) and China (Yunnan) interpreted as primitive deuterostomes: PLoS ONE, v. 5, e9586.

Caron, J.-B., Gaines, R.R., Mángano, M.G., Streng, M., and Daley, A.C., 2010, A new Burgess Shale-type assemblage from the "thin" Stephen Formation of the southern Canadian Rockies: Geology, v. 38, p. 811-814.

Caron, J.-B., and Jackson, D.A., 2008, Paleoecology of the Greater Phyllopod Bed community, Burgess Shale: Palaeogeography, Palaeoclimatology, Palaeoecology, v. 258, p. 222-256

Caron, J.-B., Scheltema, A.H., Schander, C., and Rudkin, D., 2006, A softbodied mollusc with a radula from the Middle Cambrian Burgess Shale: Nature, v. 442, p. 159-163.

Cartwright, P., Halgedahl, S.L., Hendricks, J.R., Jarrard, R.D., Marques, A.C., Collins, A.G., and Lieberman, B.S., 2007, Exceptionally preserved jellyfishes from the Middle Cambrian: PLoS ONE, v. 2, e1121.

Chen, J.-Y., Waloszek, D., and Maas, A., 2004, A new 'great-appendage' arthropod from the Lower Cambrian of China and homology of chelicerate chelicerae and raptorial antero-ventral appendages: Lethaia, v. 37, p. 3-20.

Chen, J.-Y., and Zhou, G.Q., 1997, Biology of the Chengjiang fauna: Bulletin of the National Museum of Natural Science, Taiwan, v. 10, p. 11-105.

Chen, J.-Y., Zhu, M.-Y., and Zhou, G.Q., 1995, The early Cambrian medusiform metazoan Eldonia from the Chengjiang Lagerstätte: Acta Palaeontologica Polonica, v. 40, p. 213-244. 
Chlupáč, I., and Kordule, V., 2002, Arthropods of Burgess Shale type from the Middle Cambrian of Bohemia (Czech Republic): Bulletin of the Czech Geological Survey, v. 77, p. 167-182.

Clark, A.H., 1912, Restoration of the genus Eldonia, a genus of free swimming holothurians from the Middle Cambrian: Zoologisches Anzeiger, v. 39, p. 723-725.

Collins, D., Briggs, D.E.G., and Conway Morris, S., 1983, New Burgess Shale fossil sites reveal Middle Cambrian faunal complex: Science, v. 222, p. $163-167$.

Conway Morris, S., 1985, The Middle Cambrian metazoan Wiwaxia corrugata (Matthew) from the Burgess Shale and Ogygopsis Shale, British Columbia, Canada: Philosophical Transactions of the Royal Society of London, v. B307, p. 507-586.

Conway Morris, S., 1989, The persistence of Burgess Shale-type faunas, implications for the evolution of deeper-water faunas: Transactions of the Royal Society of Edinburgh, Earth Sciences, v. 80, p. 271-283.

Conway Morris, S., 1998. The crucible of creation: the Burgess Shale and the rise of animals: Oxford, Oxford University Press, xxiii $+242 \mathrm{pp}$

Conway Morris, S., and Caron, J.-B., 2007, Halwaxiids and the early evolution of the lophotrochozoans: Science, v. 315, p. 1255-1258.

Conway Morris, S., and Peel, S., 1995, Articulated halkieriids from the Lower Cambrian of North Greenland and their role in early protostome evolution: Philosophical Transactions of the Royal Society of London B, v. 347, p. $305-358$

Conway Morris, S., and Peel, J.S., 2008, The earliest annelids: Lower Cambrian polychaetes from the Sirius Passet Lagerstätte, Peary Land, North Greenland: Acta Palaeontologica Polonica, v. 53, p. 137-148.

Conway Morris, S., and Peel, J.S., 2010, New palaeoscolecidan worms from the Lower Cambrian, Sirius Passet, Latham Shale and Kinzers Shale: Acta Palaeontologica Polonica, v. 55, p. 141-156.

Conway Morris, S., and Robison, R.A., 1986, Middle Cambrian priapulids and other soft-bodied fossils from Utah and Spain: The University of Kansas Paleontological Contributions, v. 117, p. 1-22.

Conway Morris, S., and Robison, R.A., 1988, More soft-bodied animals and algae from the Middle Cambrian of Utah and British Columbia: The University of Kansas Palaeontological Contributions, v. 122, p. 1-48.

Copeland, M.J., 1993, Anomalocaris (of unknown affinity) and Tuzoia (a possible arthropod) from the Lower Cambrian Eager Formation, near Cranbrook, British Columbia: Bulletin of the Geological Survey of Canada, v. 444 , p. $1-5$.

Daley, A.C., and Peel, J.S., 2010, A possible anomalocaridid from the Cambrian Sirius Passet Lagerstätte, North Greenland: Journal of Paleontology, v. 84, p. 352-355.

Daley, A.C., Budd, G.E., and Caron, J.-B., 2013, Morphology and systematics of the anomalocaridid arthropod Hurdia from the Middle Cambrian of British Columbia and Utah: Journal of Systematic Palaeontology, v. 11, p. $743-787$.

Durham, J.W., 1974, Systematic position of Eldonia ludwigi Walcott: Journal of Paleontology, v. 48, p. 750-755.

Dzik, J., Zhao, Y.-L., and Zhu, M-Y., 1997, Mode of life of the Middle Cambrian eldonioid lophophorate Rotadiscus: Palaeontology, v. 40, p. 385-396.

Edgecombe, G.D., 2010, Arthropod phylogeny: an overview from the perspectives of morphology, molecular data and the fossil record: Arthropod Structure \& Development, v. 39, p. 74-87.

Edgecombe, G.D., García-Bellido, D.C., and Paterson, J.R., 2011, A new leanchoiliid megacheiran arthropod from the Lower Cambrian Emu Bay Shale, South Australia: Acta Palaeontologica Polonica, v. 56, p. 385-400.

English, A.M., and Babcock, L.E., 2010, Census of the Indian Springs Lagerstätte, Poleta Formation (Cambrian), Western Nevada, USA: Palaeogeography, Palaeoclimatology, Palaeoecology, v. 295, p. 236-244.

Fatka, O., Kraft, P., and Szabad, M., 2011, Shallow-water occurrence of Wiwaxia in the Middle Cambrian of the Barrandian area, Czech Republic: Acta Palaeontologica Polonica, v. 56, p. 871-875.

Friend, D., 1995, Palaeobiology of Palaeozoic medusiform stem group echinoderms: University of Cambridge, unpublished $\mathrm{PhD}$ dissertation.

Friend, D., Zhuravlev, A.Y., and Solov'ev, I.A., 2002, Middle Cambrian Eldonia from the Siberian Platform: Paleontological Journal, v. 36, p. 20-24.

Gaines, R.R., and Droser, M.L., 2002, Depositional environments, ichnology, and rare soft-bodied preservation in the Lower Cambrian Latham Shale, east Mojave, in Corsetti, F.A., ed., SEPM Pacific Section Book 93: ProterozoicCambrian of the Great Basin and beyond: Tulsa, SEPM, p. 153-164.

Gaines, R.R., and Droser, M.L., 2005, The palaeoenvironmental context of Burgess Shale-type biotas in the three Utah Lagerstätten (USA): Acta Micropalaeontologica Sinica, v. 22, Supplement, p. 40-47.

Gaines, R.R., and Droser, M.L., 2010, The paleoredox setting of Burgess Shaletype deposits: Palaeogeography, Palaeoclimatology, Palaeoecology, v. 297, p. 649-661.

Gaines, R.R., Kennedy, M.J., and Droser, M.L., 2005, A new hypothesis for organic preservation of Burgess Shale taxa in the Middle Cambrian Wheeler
Formation, Howe Range, Utah: Palaeogeography, Palaeoclimatology, Palaeoecology, v. 220, p. 193-205.

Gámes Vintaned, J.A., Liñán, E., and Zhuravlev, A.Y., 2011, A new early Cambrian lobopod-bearing animal (Murero, Spain) and the problem of the ecdysozoan early diversification, in Pontarotti, P., ed. Evolutionary biology concepts, biodiversity, macroevolution and genome evolution: Berlin, Springer-Verlag, p. 193-219.

García-Bellido, D.C., Alvarez, M.E.D., Gamez Vintaned, J.A., Liñán, E., and Gozalo, R., 2011, First report of Crumillospongia (Demospongea) from the Cambrian of Europe (Murero biota, Spain): Bulletin of Geosciences, v. 86, p. 641-650.

García-Bellido, D.C., and Collins, D.H., 2006, A new study of Marrella splendens (Arthropoda, Marrellomorpha) from the Middle Cambrian Burgess Shale, British Columbia, Canada: Canadian Journal of Earth Sciences, v. 43, p. 721-742.

Garson, D.E., Gaines, R.R., Droser, M.L., Liddell, W.D., and Sappenfield, A., 2012, Dynamic palaeoredox and exceptional preservation in the Cambrian Spence Shale of Utah: Lethaia, v. 45, p. 164-177.

Gehling, J.G., Jago, J.B., Paterson, J.R., García-Bellido, D.C., and Edgecombe, G.D., 2011, The geological context of the Lower Cambrian (series 2) Emu Bay Shale Lagerstätte and adjacent stratigraphic units, Kangaroo Island, South Australia: Australian Journal of Earth Sciences, v. 58, p. 243-257.

Gunther, L.F., and Gunther, V.G., 1981, Some Middle Cambrian fossils of Utah: Brigham Young University Geology Studies, v. 28, p. i-iv + 1-81.

Halgedahl, S.L., Jarrard, R.D., Brett, C.E., and Allison, P.A., 2009, Geophysical and geological signatures of relative sea level change in the upper Wheeler Formation, Drum Mountains, west-central Utah: a perspective into exceptional preservation of fossils: Palaeogeography, Palaeoclimatology, Palaeoecology, v. 277, p. 34-56.

Harvey, T.H.P., Ortega-Hernández, J., Lin, J.-P., Zhao, Y.-L., and Butterfield, N.J., 2012, Burgess Shale-type microfossils from the Middle Cambrian Kaili Formation, Guizhou Province, China: Acta Palaeontologica Polonica, v. 57, p. $423-436$.

Haug, J.T., Waloszek, D., Maas, A., Liu, Y., and Haug, C., 2012, Functional morphology, ontogeny and evolution of mantis shrimp-like predators in the Cambrian: Palaeontology, v. 55, p. 369-399.

Hendricks, J.R., and Lieberman, B.S., 2008, New phylogenetic insights into the Cambrian radiation of arachnomorph arthropods: Journal of Paleontology, v. 82 , p. $585-594$.

Henriksen, K.L., 1928, Critical notes upon some Cambrian arthropods described by Charles D. Walcott: Videnskabelige Meddeleser fra Dansk Naturhistorisk Forening, Kjøbenhavn, v. 86, p. 1-20.

Hintze, L.F., 1988, Geologic history of Utah: Brigham Young University Geology Studies: Special Publication, v. 7, 202. p.

Hou, X.-G., 1987, Two new arthropods from Lower Cambrian, Chengiiang, eastern Yunnan: Acta Palaeontologica Sinica, v. 26, p. 236-256. [In Chinese, with English summary].

Hou, X.-G., and Bergström, J., 1997, Arthropods of the Lower Cambrian Chengjiang fauna, southwest China: Fossils and Strata, v. 45, p. 1-116.

Hou, X.-G., and Bergström, J., 2003, The Chengjiang fauna: the oldest preserved animal community: Paleontological Research (Japan), v. 7, p. 55-70.

Hu, S.-X., Zhu, M.-Y., Steiner, M., Luo, H.L., Zhao, F.-C., and Liu, Q., 2010, Biodiversity and taphonomy of the early Cambrian Guanshan biota, eastern Yunnan: Science China: Earth Sciences, v. 53, p. 1765-1773.

Ineson, J.R., and Peel, J.S., 2011, Geological and depositional setting of the Sirius Passet Lagerstätte (Early Cambrian), North Greenland: Canadian Journal of Earth Sciences, v. 48, p. 1259-1281.

Ivantsov, A.Y., Zhuravlev, Y.A., Leguta, A.V., Krassilov, V.A., Melnikova, L.M., and Ushatinskaya, G.T., 2005, Palaeoecology of the early Cambrian Sinsk biota from the Siberian platform: Palaeogeography, Palaeoclimatology, Palaeoecology, v. 220, p. 69-88.

Jago, J.B., and Anderson, A., 2004, A late Middle Cambrian bivalved arthropod with antennae from Tasmania: Memoirs of the Association of Australasian Palaeontologists, v. 30, p. 79-81.

Johnston, K.J., Johnston, P.A., and Powell, W.G., 2009, A new Middle Cambrian, Burgess Shale-type biota, Bolaspidella Zone, Chancellor basin, southeastern British Columbia: Palaeogeography, Palaeoclimatology, Palaeoecology, v. 277, p. 106-126.

Kimmig, J., and Pratt, B.R., 2015, Soft-bodied biota from the middle Cambrian (Drumian) Rockslide Formation, Mackenzie Mountains, northwestern Canada: Journal of Paleontology, v. 89, p. 51-71.

Legg, D., 2013, Multi-segmented arthropods from the Middle Cambrian of British Columbia (Canada): Journal of Paleontology, v. 87, p. 493-501.

Lerosey-Aubril, R., Ortega-Hernandez, J., Kier, C., and Bonino, E., 2013, Occurrence of the Ordovician-type aglaspid Tremaglaspis in the Cambrian Weeks Formation (Utah, USA): Geological Magazine, v. 150, p. 945-951.

Liddell, W.D., Wright, S.H., and Brett, C.E., 1997, Sequence stratigraphy and paleoecology of the Middle Cambrian Spence Shale in northern Utah 
and southern Idaho: Brigham Young University Geology Studies, v. 42 p. $59-78$.

Lin, J.-P., 2006, Taphonomy of naraoiids (Arthropoda) from the Middle Cambrian Kaili biota, Guizhou province, South China: Palaios, v. 21, p. 15-25

Liu, Q., 2013, The first discovery of Marrella (Arthropoda, Marrellomorpha) from the Balang Formation (Cambrian series 2) in Hunan, China: Journal of Paleontology, v. 87, p. 391-394.

Loduca, S.T., Caron, J.-B., Schiffbauer, J.D., Xiao, S.-H., and Kramer, A., 2013, A re-examination of Yuknessia Walcott, 1919 from the Cambrian of British Columbia and Utah: Geological Society of America, Abstracts with Program, v. 243, p. 123-126.

Mankiewicz, C., 1992, Obruchevella and other microfossils in the Burgess Shale: preservation and affinity: Journal of Paleontology, v. 66, p. 717-729.

Marshall, C.P., 2006, Explaining the Cambrian "explosion" of animals: Annual Review of Earth and Planetary Sciences, v. 34, p. 355-384.

Masiak, M., and Żylińska, A., 1994, Burgess Shale-type fossils in Cambrian sandstones of the Holy Cross Mountains: Acta Palaeontologica Polonica, v. 39, p. 329-340.

Matthew, G.F., 1899, Studies on Cambrian faunas. Upper Cambrian fauna of Mount Stephen, British Columbia: The trilobites and worms. Transactions of the Royal Society of Canada, v. 5, p. 39-66.

Metschnikoff, V.E., 1881, Über die systematische Stellung von Balanoglossus: Zoologischer Anzeiger, v. 4, p. 139-157.

Moore, R.A., and Lieberman, B.S., 2009, Preservation of early and middle Cambrian soft-bodied arthropods from the Pioche Shale, Nevada, USA: Palaeogeography, Palaeoclimatology, Palaeoecology, v. 277, p. 57-62.

Ortega-Hernández, J., Braddy, S.J., Jago, J.B., and Baillie, P.W., 2010, A new aglaspidid arthropod from the upper Cambrian of Tasmania: Palaeontology, v. 53 , p. $1065-1076$

Ortega-Hernández, J., Legg, D.A., and Braddy, S.J., 2013, The phylogeny of aglaspidid arthropods and the internal relationships within Artiopoda: Cladistics, v. 29, p. 15-45.

Paterson, J.R., Edgecombe, G.D., García-Bellido, D.C., Jago, J.B., and Gehling, J.G., 2010, Nektaspid arthropods from the lower Cambrian Emu Bay Shale lagerstätte, South Australia, with a reassessment of lamellipedian relationships: Palaeontology, v. 53, p. 377-402.

Paterson, J.R., García-Bellido, D.C., Lee, M.S.Y., Brock, G.A., Jago, J.B., and Edgecombe, G.D., 2011, Acute vision in the giant Cambrian predator Anomalocaris and the origin of compound eyes: Nature, v. 480, p. 237-240.

Peel, J.S., and Ineson, J.R., 2011, The extent of the Sirius Passet Lagerstätte (early Cambrian) of Greenland: Bulletin of Geosciences, v. 86, p. 535-543

Porter, S.M., 2004, Halkieriids in Middle Cambrian phosphatic limestones from Australia: Journal of Paleontology, v. 78, p. 574-590.

Randell, R.D., Liebermann, B.S., Hasiotis, S.T., and Pope, M.C., 2005, New chancelloriids from the early Cambrian Sekwi Formation with a comment on chancelloriid affinities: Journal of Paleontology, v. 79, p. 987-996.

Repina, L.N., and Okuneva, O.-G., 1969, Cambrian arthropods of the Maritime Territory: Paleontological Journal, v. 1969, 1, p. 95-103.

Resser, C.E., 1939a, The Ptarmigania strata of the northern Wasatch Mountains: Smithsonian Miscellaneous Collections, v. 97, 12, p. 1-29.

Resser, C.E., 1939b, The Spence Shale and its fauna: Smithsonian Miscellaneous Collections, v. 98, 24, p. 1-72.

Rigby, J.K., 1983, Sponges of the Middle Cambrian Marjum Limestone from the House Range and Drum Mountains of western Millard County, Utah Journal of Paleontology, v. 57, p. 240-270.

Rigby, J.K., Gunther, L.F., and Gunther, F., 1997, The first occurrence of the Burgess Shale demosponge Hazelia palmata Walcott, 1920, in the Cambrian of Utah: Journal of Paleontology, v. 71, p. 994-997.

Robison, R.A., 1976, Middle Cambrian stratigraphy of the Great Basin: Brigham Young University Geology Studies, v. 23, p. 93-109.

Robison, R.A., 1991, Middle Cambrian biotic diversity: examples from four Utah Lagerstätten, in Simonetta, A.M., and Conway Morris, S., eds. The early evolution of Metazoa and the significance of problematic taxa: Cambridge, Cambridge University Press, p. 77-93.

Robison, R.A., and Babcock, L.E., 2011, Systematics, paleobiology, and taphonomy of some exceptionally preserved trilobites from Cambrian Lagerstätten of Utah: Paleontological Contributions, v. 5, p. 47.

Robison, R.A., and Sprinkle, J., 1969, Ctenocystoidea: new class of primitive echinoderms: Science, v. 166, p. 1512-1514.

Robison, R.A., and Wiley, E.O., 1995, A new arthropod, Meristosoma: more fallout from the Cambrian explosion: Journal of Paleontology, v. 69, p. $447-459$.

Schwimmer, D.R., and Montante, W.M., 2007, Exceptional fossil preservation in the Conasauga Formation, Cambrian, northwestern Georgia, USA: Palaios, v. 22, p. $360-372$.

Selden, P.A., 2014, A workflow for digital photography of fossil specimens: The Geological Curator, v. 10, p. 93-98.

Skinner, E.S., 2005, Taphonomy and depositional circumstances of exceptionally preserved fossils from the Kinzers Formation (Cambrian), southeastern
Pennsylvania: Palaeogeography, Palaeoclimatology, Palaeoecology, v. 220 p. $167-192$

Smith, M.R., 2012, Mouthparts of the Burgess Shale fossils Odontogriphus and Wiwaxia: implications for the ancestral molluscan radula: Proceedings of the Royal Society of London, B, v. 279, p. 4287-4295.

Smith, M.R., 2014, Ontogeny, morphology and taxonomy of the soft-bodied Cambrian 'mollusc' Wiwaxia: Palaeontology, v. 57, p. 215-229.

Stein, M., Budd, G.E., and Peel, J.S., 2013, Arthroaspis n. gen., a common element of the Sirius Passet Lagerstätte (Cambrian, North Greenland), sheds light on trilobite ancestry: BMC Evolutionary Biology, v. 13, p. e99.

Stein, M., Church, S.B., and Robison, R.A., 2011, A new Cambrian arthropod, Emeraldella brutoni, from Utah: Paleontological Contributions, v. 3, p. 9.

Steiner, M., Hu, S.-X., Liu, J., and Keupp, H., 2012, A new species of Hallucigenia from the Cambrian Stage 4 Wulongqing Formation of Yunnan (South China) and the structure of sclerites in lobopodians: Bulletin of Geosciences, v. 87, p. 107-124.

Struck, T.H., 2011, Direction of evolution within Annelida and the definition of Pleistoannelida: Journal of Zoological Systematics and Evolutionary Research, v. 49, p. 340-345.

Sun, H.-J., Zhao, Y.-L., Peng, J., and Yang, Y.-N., 2014, New Wiwaxia material from the Tsinghsutung Formation (Cambrian Series 2) of eastern Guizhou, China: Geological Magazine, v. 151, p. 339-348.

von Siebold, C.T., 1848. Lehrbuch der vergleichenden Anatomie. Teil 1. Lehrbuch der vergleichenden Anatomie der wirbellosen Thiere: Berlin, Veit, $679 \mathrm{pp}$.

Waggoner, B., and Hagadorn, J.W., 2004, An unmineralized alga from the Lower Cambrian of California, USA: Neues Jahrbuch für Geologie und Paläontologie, Abhandlungen, v. 231, p. 67-83.

Walcott, C.D., 1908, Cambrian trilobites: Smithsonian Miscellaneous Collections, v. 53, p. 13-52.

Walcott, C.D., 1911a, Middle Cambrian annelids: Smithsonian Miscellaneous Collections, v. 57, p. 109-144.

Walcott, C.D., 1911b, Middle Cambrian holothurians and medusa: Smithsonian Miscellaneous Collections, v. 57, p. 41-68.

Walcott, C.D., 1912, Middle Cambrian Branchiopoda, Malacostraca, Trilobita and Merostomata: Smithsonian Miscellaneous Collections, v. 57, p. $145-228$.

Walcott, C.D., 1919, Middle Cambrian algae: Smithsonian Miscellaneous Collections, v. 67 , p. $217-259$.

Walcott, C.D., 1920, Middle Cambrian Spongiae: Smithsonian Miscellaneous Collections, v. 67 , p. 261-364.

Webster, M., Gaines, R.R., and Hughes, N.C., 2008, Microstratigraphy, trilobite biostratinomy, and depositional environment of the "Lower Cambrian" Ruin Wash Lagerstätte, Pioche Formation, Nevada: Palaeogeography, Palaeoclimatology, Palaeoecology, v. 264, p. 100-122.

Whittington, H.B., 1971, Redescription of Marrella splendens (Trilobitoidea) from the Burgess Shale, Middle Cambrian, British Columbia: Bulletin of the Geological Survey of Canada, v. 209, p. 1-24.

Whittington, H.B., 1974, Yohoia Walcott and Plenocaris n. gen., arthropods from the Burgess Shale, Middle Cambrian, British Columbia: Bulletin of the Geological Survey of Canada, v. 231, p. viii +27 p.

Xiao, S.-H., Hu, J., Yuan, X.-L., Parsley, R.L., and Cao, R.-J., 2005, Articulated sponges from the Lower Cambrian Hetang Formation in southern Anhui, South China:. their age and implications for the early evolution of sponges: Palaeogeography, Palaeoclimatology, Palaeoecology, v. 222, p. 89-117.

Yang, J., Smith, M.R., Lan, T., Hou, J.-B., and Zhang, X.-G., 2014, Articulated Wiwaxia from the Cambrian Stage 3 Xiaoshiba Lagerstätte: Scientific Reports, v. 4, e4643.

Yang, J., Ortega-Hernández, J., Butterfield, N.J., and Zhang, X.-G., 2013, Specialized appendages in fuxianhuiids and the head organization of early euarthropods: Nature, v. 494, p. 468-471.

Yang, K.-D., Zhao, Y.-L., Yang, X.-L., Da, Y., and Wu, Z.-T., 2011, Discovery of Kaili biota from the Zhenyuan area of Guizhou: Acta Palaeontologica Sinica, v. 50, p. 176-186. [In Chinese, with English summary].

Zhang, X.-L., and Hua, H., 2005, Soft-bodied fossils from the Shipai Formation, lower Cambrian of the Three Gorge area, South China: Geological Magazine, v. 142, p. 699-709.

Zhang, X.-L., Liu, W., and Zhao, Y.-L., 2008, Cambrian Burgess Shale-type Lagerstätten in South China: distribution and significance: Gondwana Research, v. 14, p. 255-262.

Zhao, F.-C., Smith, M.R., Yin, Z.-J., Zeng, H., Hu, S.-X., Li, G.-X., and Zhu, M.-Y., 2015, First report of Wiwaxia from the Cambrian Chengjiang Lagerstätte: Geological Magazine, v. 152, p. 378-382.

Zhao, Y.-L., Qian, Y., and Li, X.-S., 1994, Wiwaxia from early-middle Cambrian Kaili Formation in Taijiang, Guizhou: Acta Palaeontologica Sinica, v. 33, p. 359-366. [In Chinese, with English summary].

Zhao, Y.-L., Yuan, J.-L., Zhu, M.-Y., Yang, X.-L., and Peng, J., 2003, The occurrence of the genus Marrella (Trilobitoidea) in Asia: Progress in Natural Science, v. 13, p. 708-711. 
Zhao, Y.-L., and Zhu, M.-Y., 1994, Medusiform fossils of Kaili fauna from Taijiang, Guizhou: Acta Palaeontologica Sinica, v. 33, p. 272-280. [In Chinese, with English summary].

Zhao, Y.-L., Zhu, M.-Y., Babcock, L.E., Yuan, J.-L., Parsley, R.L., Peng, J., Yang, X.-L., and Wang, Y., 2005, Kaili biota: a taphonomic window on diversification of metazoans from the basal Middle Cambrian: Guizhou, China: Acta Geologica Sinica (English edition), v. 79, p. 751-765.
Zhu, M.-Y., Zhao, Y.-L., and Chen, J.-Y., 2002, Revision of the Cambrian discoidal animals, Stellostomites eumorphus and Pararotadiscus guizhouensis from South China: Geobios, v. 35, p. 165-185.

Accepted 23 June 2015 